in 1949, and has since then fostered the development of the Royal Technical College of East Africa in Nairobi--which was officially opened by Princess Margaret last October - of the Nigerian College of Arts, Science and Technology with branches in the three regions of Nigeria, and of Kumasi College of Technology, in Ghana. It has also assisted with the development of Fourah Bay College in Sierra Leone, and with the setting-up of the Singapore Polytechnic. The Committee is advising on the establishment of technical colleges in the West Indies. As Advisory Committee on grants for higher technical education under the Colonial Development and Welfare Acts, it has always worked in close contact, with the Colonial Office.

The chairman of the new Council is Sir David Lindsay Keir, master of Balliol College, Oxford, who was chairman of the Advisory Committee. Its other sixteen members, who were also members of the Advisory Committee, include prominent educationists with wide experience of education in the overseas territories and leading figures in the field of technical education in the United Kingdom; provision has also been made for three co-opted members to be added to the Council. Payment for the Council's secretariat and overhead expenses is made largely from Colonial Development and Welfare funds. The main function of the Council is to advise the Secretaries of State for Commonwealth Relations and for the Colonies, overseas governments, governing councils of overseas colleges and other interested organizations on the development of colleges of arts, science and technology. These are defined as colleges which offer courses of gencral, scientific and technical education leading to professional or near-professional qualifications (not, normally, university degrees) and which encourage research -including colleges which offer, in addition, courses of a lower standard. It will be ready to assist in the recruitment of staff, and to advise on matters of academic policy. It will also seek to stimulate the interest of technical and other institutions in the United Kingdom in the overseas colleges, and to assist examining bodies and professional institutions in Britain on courses, exam. inations and qualifications specially designed to meet the needs of overseas students. To avoid duplication of effort, the Council will maintain close liaison with the Inter-University Council for Higher Education Overseas and with the Colonial University Grants Advisory Committee. It will also maintain close liaison with the Advisory Committee on Education in the Colonies, with the object of relating the work of the Colleges to that of other educational institutions, particularly those giving trade and technical training.

\section{The Journal of Solar Energy Science and Engineering}

Publicatron of a new journal intended to cater for the growing interest in practical developments of the utilization of solar energy (Journal of Solar Energy Science and Engineering. Pp. 64. Subscription rate: 10 dollars per year. Phoenix, Arizona: Association for Applied Energy, 1957) commenced in January as one consequence of the First World Symposium on Applied Solar Energy held in Arizona, 1955. The first issue contains articles describing a wide range of solar energy applications. Variation of solar radiation and an analysis of the effects of season and orientation of the Sun; latitude, altitude and cloudiness at the place of reception are the subjects of two papers of importance in assessing the potential value of heat collectors. A contribution from Russian scientists describes experiments in the U.S.S.R., and the projected design of a solar boiler of steaming capacity about 12 tons per hour. Other papers are concerned with photosynthesis, the design of solar furnaces and the production of cold by solar radiation. A review of world research activities on solar energy and abstracts from the literature forms a useful guide to present developments.

Volume 1, Nos. 2 and 3, published in July 1957 , have been combined as the Proceedings of the 1957 Symposium at Phoenix on Solar Furnaces. A collection of twenty papers describes various applications, the principles of design and methods of control, industrial and economic factors in their use. The present largest mirror, $35 \mathrm{ft}$. in diameter, is at Montlouis in the Pyrenecs, under the direction of $\mathrm{M}$. Felix Trombe, but mirrors up to $100 \mathrm{ft}$. in diameter are being designed by the Stanford Research Institute. These solar furnaces are used mainly for research on the properties of materials at temperatures up to $3,000^{\circ} \mathrm{C}$, and in some cases are linked with research on high-velocity rockets and nuclear developments. This valuable survey indicates that solar furnaces have many research applications in localities where solar radiation is intense, but the development of these for routine manufacturing processes is still a matter for the future.

\section{Tower for Optical Testing}

ThE manufacture of telescope mirrors requires extensive optical testing of the reflecting surfaces. In the past this has been performed in a horizontal tunnel with the mirror standing on edge. This method proved satisfactory for mirrors of moderate size, but for very large mirrors a still better technique was desired. The use of a horizontal tunnel has the disadvantage that the mirror in its cell is not sup. ported in the same manner as it would be in the completed telescope. To overcome this difficulty, Sir Howard Grubb, Parsons and Co., Ltd., of Walkergate, Newcastle upon Tyne, have constructed a tower, $100 \mathrm{ft}$. high, for the optical testing of large mirrors. The mirror under test is supported horizontally at the bottom of the tower. A number of floors at various heights inside the tower provide access to the optical axis of the mirror; each floor has a central hole through which the light beam mar pass. Special precautions are being taken to ensure constant temperature conditions inside the tower.

\section{International Abstracts of Biological Sciences}

LAST October it was announced (see Nature, 178, $726 ; 1956$ ) that the Council of Biological and Medical Abstracts, Ltd., proposed to change the name of British Abstracts of Medical Sciences to International Abstracts of Biological Sciences. This change has now occurred, and it emphasizes two important developments in the character of the journal. The abstracts now include a wider range of subjects and they also cover the Russian literature. The inclusion of subjects not previously covered has been promoted by the appointment to the Council of representatives from the Society for Experimental Biology. A variety of other improvements have also been incorporated, and International Abstracts of Biological Sciences now provides a comprehensive abstracting service for the experimental and biochemical aspects of biology. The journal is published by the Pergamon Press for 